\title{
Training and Capacity Building in Creating Multiple Intelligence-Oriented Instructional Media for Elementary School Teachers
}

\author{
Ignatius I Wayan Suwatra ${ }^{1}$, I Km. Sudarma², Adr. I Wy. Ilia Yuda Sukmana ${ }^{3}$, Dewa Gede \\ Agus Putra Prabawa ${ }^{4}$ \\ \{Wayansuwatra3@gmail.com¹, AIWIY-sukmana@undiksha.ac.id² , IK-sudarma@undiksha.ac.id², \\ dewaprabawa2@gmail.com $\left.{ }^{4}\right\}$ \\ Universitas Pendidikan Ganesha, Indonesia ${ }^{1,2,3,4}$
}

\begin{abstract}
This study is aimed at improving knowledge and skill of elementary school teachers in Buleleng district at making instructional media that target children across all levels and of multiple intelligences. The target participants of this activity were 30 elementary school teachers in Buleleng district. It was split into three stages: general training, intensive building of the teachers' capacity and evaluation of the implementation process, and results of the activity. The participants' attendance was $100 \%$ which indicates the research activity was a success. At the end of the capacity building exercise, four instructional resources were produced: a wayang (puppet); a counting box; comic strips; and a cultural needle. The data analysis showed that all four products produced, (wayang, the computing box, the comic strips, and the cultural needle) qualified as very good. Overall, the resources produced were rated as very good.
\end{abstract}

Keywords: Instructional Media, Multiple intelligences, elementary school teacher.

\section{Introduction}

A teacher is an important component in learning at school. Without the help of a teacher, interest, ability, aptitude and other potentials possessed by a child cannot be developed optimally [6]. Teacher performance is very much determined by their competence. To be successful in teaching effectively, the teacher has to understand the individual differences of the students and design resources to aid those specific needs in order to develop each child's potential. However, the reality is that not all teachers are able to develop and empower individual levels of intelligence optimally in teaching due to several different factors, including lack of awareness regarding these issues. In a study conducted by Sudarma and Adnyana [9] of lesson plans written by teachers in Buleleng district, it was found that the instructional media used had not specifically helped the students in developing their intelligences.

In relation to this, a preliminary study was conducted, and the problems identified in elementary schools throughout Buleleng district included (1) The practice of teaching done by the teachers in general still focused primarily on the development of academics (linguistic and mathematical-logic). (2) The teachers still focused on the mastery of materials by the students. 
(3) Knowledge and understanding of the teachers on the empowerment of individual intelligences in elementary schools were still low. (4) The teachers' skills in making instructional media tailored to multiple intelligences were still low. These problems should be overcome soon.

In keeping with the effort to solve these problems, a confirmation was produced via distributing questionnaires to 20 teachers at 10 SDs in Buleleng district, of whom were selected at random. The teachers were given the opportunity to select out of the four different options: training to make an assessment and evaluation; training on teaching strategies; training to make instructional media/visual aids; training in using multimedia/educative games. It was found that the most popular option was training to make instructional media/visual aids, with a total of 16 teachers selecting the option (80\%). The limited availability of instructional media prevents teachers from helping students fulfil their potential. In light of this, there is a significant need to make an effort to improve knowledge and skill of elementary school teachers in making instructional resources tailored to children with different levels of ability at elementary school. This effort was made through training and capacity building.

Gardner defines intelligence as the ability to solve problems and to produce products in a setting with variations in the real situation [4]. There are nine types of intelligence that belong to multiple intelligences: 1) linguistic intelligence, 2) mathematical-logic, 3) spatial intelligence, 4) kinaesthetic - physical intelligence, 5) musical intelligence, 6) interpersonal intelligence, 7) intrapersonal intelligence, 8) naturalistic/environmental intelligence, and 9) existential intelligence. The complete description is as follows.

Table 1.Classification of Multiple intelligences

\begin{tabular}{|c|c|c|}
\hline Intelligence & Definition & Outstanding abilities \\
\hline Linguistic & $\begin{array}{l}\text { Ability to use and process words } \\
\text { effectively both orally and in } \\
\text { writing such that is possessed by } \\
\text { poets, editors, journalists, } \\
\text { playwrights, men or women of } \\
\text { letters, actors and orators. }\end{array}$ & 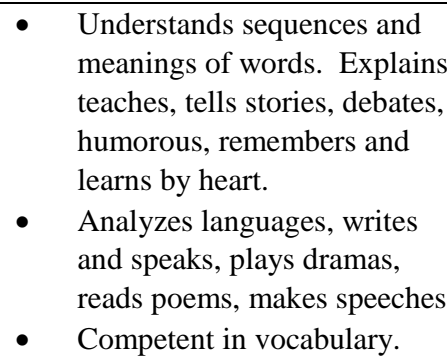 \\
\hline \multirow[t]{2}{*}{ Mathematical-logical } & $\begin{array}{l}\text { Ability to use numbers and logic } \\
\text { effectively. Usually } \\
\text { mathematicians, scientists, } \\
\text { programmers and logicians. }\end{array}$ & $\begin{array}{ll}\text { - } & \text { Logic. } \\
\text { - } & \text { Reasoning, patterns sebab- } \\
\text { akibat. }\end{array}$ \\
\hline & & $\begin{array}{l}\text { - } \quad \text { Classifies and categorizes. } \\
\text { - } \quad \text { Instraction, symbolization. } \\
\text { thinking. } \\
\text { - } \quad \text { Counts and plays with } \\
\text { numbers. } \\
\text { - } \\
\text { - } \\
\text { Pcientific thinking. } \\
\text { Problem solving. }\end{array}$ \\
\hline
\end{tabular}


Spatial-visual

Kinaesthetic-physical

Musical
Ability to understand the spatialvisual world with a precision such as that possessed by a hunter, an architect, a decorator.

Ability to use one's body to express ideas and feelings such as possessed by an actor an athlete, a dancer, and a surgeon.

Ability to develop and express musical forms and sounds.
- Syllogism.

- Recognizes the relation of objects in a space in a precision.

- $\quad$ Has a precise perception from various angles.

- Representation of graphs.

- Manipulation of pictures, draws pictures.

Easy to find a way in a space.

- His or her imagination is active.

- Sensitive to colors, lines and shapes.

- Easy to express himself or herself with his or her body.

- Relates thoughts and body.

- $\quad$ Ability to mimic.

- Plays in a drama, plays a role.

- Actively moves plays a sport, dances.

- Body coordination and flexibility are high.

- $\quad$ Sensitive to sounds and music.

- Knows musical structures well.

- $\quad$ Easy to catch music.

- Creates melodies.

- Sensitive to intonations, rhythms.

- $\quad$ Sings, performs music

- Creates music.

- $\quad$ Plays an instrument. 
Interpersonal

Intrapersonal

Environment

Ecosystem
Ability to understand and anticipate feeling, temperament, emotion, intention, desire of other people and regard them appropriately.

Ability to understand oneself and is responsible for one's life.

Ability related to the understanding of floras and faunas, living environment.

Ability to answer problems related to the existence of human beings.
- $\quad$ Easy to work with friends.

- Easy to know and differentiate friends' feelings and personalities.

- Verbal and nonverbal communication.

- $\quad$ Sensitive to friends, emphatic

- Likes to give feedbacks.

- Can concentrate well.

- Awareness and expression of different feelings.

- Knows oneself deeply.

- self-balance.

- Aware of spiritual reality.

- Reflective, likes to work. alone.

- Knows floras and faunas

- Classifies and identifies plants and animals, likes nature, living outside of his or her house.

- $\quad$ Sensitive to and able to answer the problem of existence of human beings, what the meaning of life is and why we were born and die.

Source : Suparno (2004).

Resources are considered important components in teaching. In relation to the making of these resources by teachers, they have to be able to facilitate the development of some types of the intelligences above.

Some types of instructional resources that support the development of multiple intelligences are: 1). Solid models such as animal miniatures, custom dolls, house miniatures, plane miniatures etc, 2). Cutaway models such as an eyeball model, a torso model, a heart model etc, 3). Built-up models such as a fraction of a part or content volume. 4). Working sheets such as play cars, phones, agricultural engines, etc. 5). Mock-ups such as radio construction and its mechanism, etc. 6). Diorama, such as a diorama of a historical event.

\section{Method}

The training and capacity building were conducted in three stages. The first stage was a general training of 30 elementary school teachers in Buleleng district. The second, was an intensive capacity building of 30 elementary school teachers in Buleleng district to make 
instructional resources tailored to the development of the different intelligences. The third stage, evaluation that consisted of both process and product evaluation. The process evaluation was aimed at finding out the success of the implementation of the activity of training. The success of the implementation was seen from the attendance of the participants that reached $>90 \%$, as well as the active participation of the participants during the training. The product evaluation was aimed at finding out how much knowledge and skills participants acquired through the training, as assessed with the results i.e the products created. The Dataset can be accessed in osf.io/3yhga Open Science Frame work. [5]

\section{Result and Discussion}

As seen from the process, the training and capacity building for making instructional media oriented to the development of multiple intelligences for the elementary teachers in Buleleng district was successful. The success can be seen from the following results. First, from the attendance of the participants during the training, which reached $100 \%$. They were enthusiastic participating from the beginning until the end of the activity.

Secondly, from the results, the participants have been able to produce four types of resources such as 1) a wayan (puppet) to develop linguistic and spatial intelligence, 2) a counting box to develop logical/ mathematical, linguistic and spatial intelligences, 3) comic strips to develop linguistic intelligence, 4) a cultural needle to develop spatial and linguistic intelligences. The evaluation of media was done by using an evaluation rubric.

Table 2. Scores of Media Evaluation

\begin{tabular}{llll}
\hline No & Name of Media & Score & Category \\
\hline 1 & Wayang ( puppet) & 97.64 & Very Good \\
2 & Counting Box & 98.00 & Very Good \\
3 & Comic Strips & 96.25 & Very Good \\
4 & Cultural needle & 96.00 & Very Good \\
\hline
\end{tabular}

All four resources produced received scores that fall into the very good category of the rating scale used, the average score obtained reached 96.97. This indicates that the ability and skill of the teachers in making instructional resources were very good.

The success in the implementation of the training and capacity building could not be separated from the participants' enthusiasm and motivation in participating in the training. The training was interesting for the participants and could help them acquire additional knowledge and skills in creating instructional resources tailored to the various intelligences. The training of this type is rarely given in Buleleng district. In addition to this, the role of the Head of UPP of Buleleng district always encouraged and motivated the teachers to join the experiment, and other similar activities to develop competencies. This was a critical aspect that has contributed to the success of this activity. 


\section{Conclusion}

The training and capacity building in making instructional resources oriented to multiple intelligences for the elementary school teachers in Buleleng district was successful, both in terms of the process and the product. This activity was able to improve the teachers' knowledge and skills in creating tailored instructional resources that approach the multiple intelligences. This can be seen from the instructional resources produced by the teachers with the average score of 96.97, falling into the very good category.

\section{References}

[1] Amstrong, T.: Multiple Intelligences in The Classroom. Alexandria, Virginia: ASCD. 1994

[2] Asyar, H. R.: Kreatif mengembangkan media pembelajaran. Jakarta: Gaung Persada (2011)

[3] Fogarty, R.: Problem-Based Learning and Other Curriculum Models for the Multiple Intelligences Classroom. Illinois: IRI/SkyLight (1997)

[4] Gardner, H.: Multiple Intlegences. The Theory in Practice. New York: Basic Books (1999)

[5] I. I. W. Suwatra.: "A Training and Capacity Building in Making Multiple Intelligences-Oriented Instructional Media for the Elementary School Teachers," 06-Jan-2019. [Online]. Available: osf.io/3yhga.

[6] Mulyasa, E.: Menjadi Guru Profesional: Menciptakan Pembelajaran Kreatif dan Menyenangkan. Bandung: PT Remaja Rosdakarya (2008)

[7] Rohani, A.: Media instruksional edukatif. Jakarta: PT Rineka Cipta (1997)

[8] Santrock, J.W.: Psikologi Pendidikan (terjemahan). Jakarta: Kencana (2007)

[9] Sudarma, I Komang \& Putu Budi Adnyana.: Pengembangan Butik (Buklet Tematik Integratif Kontekstual) Untuk Memberdayakan Kecerdasan Multitalenta Siswa Sekolah Dasar (SD). Laporan Penelitian. Universitas Pendidikan Ganesha (2015)

[10] Suparno, P.: Teori Intelegensi Ganda dan Aplikasinya di Sekolah. Yogyakarta: Kanisius.

[11] Sutirjo dan Mamik, S.I.: 2005. Tematik: Pembelajaran Efektif dalam Kurikulum 2004. Malang: Bayumedia (2004) 